\title{
Microbe loads in washed and unwashed vegetables' water in samaru market, Nigeria
}

\author{
Odunze $^{1}$, Ivy Ihuoma, Odubu ${ }^{1}$, Uyoyo Mary, Okwori' ${ }^{2}$ Esther, Onu ${ }^{2}$ Rose, O. and Natala Cecilia \\ ${ }^{1}$ Home and Rural Economics Programme, Samaru College of Agriculture, Division of Agricultural Colleges (DAC/SCA), \\ Ahmadu Bello University (ABU), Zaria, Nigeria \\ ${ }^{2}$ National Agricultural Extension Research and Liaison Services (NAERLS), Ahmadu Bello University (ABU), Zaria, \\ Nigeria. \\ Corresponding Author Email: finefaceivy@gmail.com
}

\section{ABSTRACT}

\begin{abstract}
The study investigated microbial infestation load of four vegetables; carrot, cucumber, lettuce and tomatoes (washed and unwashed), as well as water samples used for washing of these produce. The objective was to determine microbial load on vegetables, possible causes of contamination, as well as efficacy of anti-microbial agents in decontaminating microorganism on vegetables. The vegetables and water samples of $50 \mathrm{~g}$ each and $100 \mathrm{ml}$ respectively were obtained from Samaru Market under aseptic conditions (in sterile plastic bags to eliminate cross contamination) and transported to the laboratory of the National Research Institute for Chemical Technology (NARICT), Basawa, Zaria, Environmental Technology Division, Microbiology Section and were preserved in iced cooler. The samples were analyzed bacteriologically by total viable count with the following results: Carrot $5.4 \times 10^{7} \mathrm{cfu} / \mathrm{g}$ unwashed and $4.7 \times 10^{4} \mathrm{cfu} / \mathrm{g}$ washed; cucumber $4.8 \times 10^{3} \mathrm{cfu} / \mathrm{g}$ unwashed and $1.8 \times 10^{3}$ washed; Lettuce 3.6.8 $\times 10^{6}$ unwashed and $2.9 \times 10^{5}$ washed and Tomatoes $5.6 \times 10^{3}$ unwashed and $3.4 \times 10^{4}$ washed. Water used to wash tomatoes $5.3 \times 10^{4} \mathrm{cfu} / \mathrm{ml}$ and water used to wash carrot, cucumber and lettuce $4.6 \times 10^{5}$ $\mathrm{cfu} / \mathrm{ml}$. Total fecal coliform count has the following results: carrot $3.9 \times 10^{5} \mathrm{cfu} / \mathrm{g}$ unwashed and $3.4 .7 \times 10^{3}$ cfu/g washed; cucumber $2.4 \times 10^{3}$ unwashed and $7.6 \times 10^{2} \mathrm{cfu} / \mathrm{g}$ washed; Lettuce $2.4 \times 10^{4} \mathrm{cfu} / \mathrm{g}$ unwashed and $8.2 \times 10^{3} \mathrm{cfu} / \mathrm{g}$ washed and Tomatoes $4.7 \times 10^{4}$ unwashed and $4.4 \times 10^{3} \mathrm{cfu} / \mathrm{g}$ washed. Water used to wash tomatoes recorded $7.2 \times 10^{3}(\mathrm{cfu} / \mathrm{ml})$ and water used to wash carrots, cucumber and lettuce $3.1 \times 10^{3}$ $\mathrm{cfu} / \mathrm{ml}$. The most probable number (MPN) of microorganisms was identified from surface of these vegetables and exceeded the World Health Organization (WHO) recommended standard for unrestricted farm produce. The result reveals that contamination of vegetables was attributable to use of contaminated water used to wash fresh produce, feaces and farmyard manures/animal waste used as manure and unhygienic handling by sellers. Appropriate management practices were recommended.
\end{abstract}

Keywords: Microbes; Water analysis, Washed and Unwashed, Market.

\section{INTRODUCTION}

Samaru is located within the city of Zaria in Kaduna State, Nigeria. It is situated at latitude $11^{\circ} 12^{\prime} \mathrm{N}$, and longitude $07^{\circ} 37^{\prime} \mathrm{E}$ at an altitude of 550-700 meters above sea level. It is cosmopolitan in nature; drawing and fusing people of diverse national and international backgrounds. This semi-urban village has mixed population with inhabitants from all parts of Nigeria owing to their variety of ethnic groups available in the district (Ujah 2012). The Samaru Market is located in Samaru, a district located in
Zaria local Government of Kaduna State. It lies along the lya Road and extends to Hayin Dogo before the railway line. The road to Samaru market is untarred and a variety of goods are sold there, ranging from food stuffs to stationeries, clothing's and cosmetics. Vegetables, plants and animal protein rich foods are consumed by individuals of all status, despite their high prices. The nutritional values of these foods compel people to consume food plant originated, particularly vegetables. 
However, the surfaces of vegetables contain a large number of micro-organism which can have deleterious effect on human health, thereby leading to food borne illnesses.

Advances in food/ vegetable processing and conservation technologies, together with their distribution and trading have made nearly all kinds of fresh vegetables available in good quality and increased health awareness; but the kind of water used in planting and tendering vegetables while in the farm, such as waste water and the washing methods employed by sellers in the local markets have increased health hazards. These washing methods include use of sanitizing chemicals, such as detergents without thorough rinsing with water, or infected water from other sources. Ihenkoronye (2012) in his findings observed that poor handling has inevitably prevented the nutritional benefits of vegetables from being achieved, with most recent estimates of over 200,000 Nigerians dying each year from contaminated foods through improper processing and preservation, of which vegetables are inclusive.

Vegetables provide essential nutrients in human diet. It is now well established that they have high nutritional value. Vegetables are low in fat and protein; the main components are usually water, fiber, starch, vitamin and minerals. As a result, people in many countries have recommended that vegetables be taken at least five times a day in their routine dish (Asgher, Ehgbaleh, Mohamadreza and Jafar, 2013). Vegetables are either eaten raw, cooked and/or are ingredients in a wide range of foods. They may also be chopped, canned, dried, frozen, salted, fermented or packaged in various ways. Apart from the great beneficial aspect of fresh vegetables, they are also a good source of food borne illnesses when contaminated with micro-organisms. These occur during cultivation with waste water and during human handling and processing with sanitizing chemicals; such as use of detergents in the local markets (Beuchat, Buck and Walcot 2003). Vegetables are consumed by humans as foods, as part of a savory course or meals and can be categorized into: Green leafy vegetables, bulbs, roots and tubers, pulses and legumes, vegetable fruits (Sue \& Demands, 2015).

They however carry besides microbial flora, pathogenic microorganisms while passing from farm to table for consumption. These microbes are permeable due to the composition of vegetables which provides a good source or substrate for the growth of any microbe which may have contaminated them from the soil, air or water and affects every step of processing, including cultivation, harvesting, transporting, packaging, storage and selling to the final consumers in local markets. These vegetables among many include cucumber, lettuce, tomatoes and carrots (Gilman, 2002).

Micro-organism which include bacteria, microscopic fungi, viruses and protoctists do have profound beneficial effects without which we would not exist such as saprophytic decomposers which play important role in breaking down dead organic matter in ecosystems, but these same micro-organisms can be responsible for food contamination and food spoilage, leading to common infectious diseases as salmonella, typhoid, cholera etc. Madigan, and Martinko, (2006), Retrieved from http://wikipedia atom feed. microorganism, 2015). Food borne illness; illness resulting from taking contaminated food and drinking contaminated water or beverages, contaminated with bacteria, parasites, viruses or harmful chemicals, especially in the case of minimally processed vegetables. Although micro-organisms do not cause food borne illnesses directly, they can impact the rate at which food spoils and facilitate spread of harmful microbes in the kitchen. It is estimated that 9.4 million illnesses and 1,351 deaths occur each year in the United States, 2000 deaths and 34000 cases of death in Africa each day and over 200,000 deaths in Nigeria each year as a result of eating contaminated food, Food and Agricultural Organization (2005), Ihenkuronye, (2012) and this has given rise to the quest for food safety.

The lack of effective antimicrobial treatment of any step from planting to consumption means that pathogens introduced at any point may be present in the final product (Ibrahim \& Ojei, 2008). Hence; everyone is at risk, but certain groups of people are particularly vulnerable to food borne illnesses; such as infant, young children, pregnant women and their unborn babies, older adults and people with weakened immune system, such as those with HIV/AIDS, cancer, diabetes, kidney diseases and transplants patients. This study therefore intends to investigate microbial load on vegetables that are water washed and unwashed, as well as the efficacy of washing procedure done in the local market, with a view to help consumers' health conditions from the consumption of safety fresh vegetables from sources like the farm and local markets and be protected from contamination and spoilage with the use of proper and hygienic washing with clean water.

Specifically therefore, objectives of the study were to determine the total bacteria load of fresh vegetables; carrot, cucumber, tomatoes and lettuce, washed and unwashed from Samaru market, Zaria.

\section{MATERIALS AND METHODS}

\section{Study Area}

Fifty grams $(50 \mathrm{~g})$ each of four vegetable samples (carrot, cucumber, lettuce and tomatoes) washed and unwashed were randomly selected from Samaru market of Sabon Gari Local Government Area in Kaduna state. The samples were analyzed in National Research Institute for Chemical Technology of Environmental Technology Division, Microbiology Section, Basawa-Zaria. 
174 Afr. J. Food Sci. Technol.

\section{Method of Sample Collection}

Experimental research method that involved microbial analysis of water from vegetables was used for the study. Two water samples, $100 \mathrm{ml}$ each were used to wash the vegetables from two different shops at Samaru market, in Sabon Gari Local Government Area of Kaduna State. A total of 10 water samples were collected from shops in Samaru Market and treated under aseptic conditions and transported to the laboratory. These were collected in sterile labeled plastic bags and bottles in order to eliminate any form of cross contamination, and then transported to National Research Institute for Chemical Technology of the Microbiology Section, Basawa-Zaria for analysis. In order to assess the possible cause of contamination of the vegetable products, $100 \mathrm{mls}$ each of water samples used to wash these vegetables were collected in sterile bottles for analysis. One sample each of washing water was collected from sellers of carrot, cucumber and lettuce and sellers of tomatoes. The samples were preserved in iced cooler to maintain cool temperature so as to stabilize and maintain the microorganisms from the site of collection prior to laboratory analysis. The efficacy of commercial vegetables washed in the market with unwashed vegetables from the farm was compared. This process was used to isolate microbes on vegetables from farm and those either acquired at transportation or in the markets for laboratory analysis. Also, microbial contamination of water on some selected vegetables was investigated through gram staining and total coliform count. The study also identifies the washing procedures employed by the local market handlers in eliminating microbial contaminants.

\section{Microbial Analysis}

Determination of microbial quality of some selected vegetables was done using laboratory analysis to obtain Total Viable Count (TVC) and Total Faecal Coliform counts (TFC), i.e., the microbial load. Distilled water was used for both serial dilution of the vegetable samples and the water samples were sterilized using an autoclave. A measure of $9 \mathrm{ml}$ each of sample water was transferred into test tubes for serial dilution analysis and $225 \mathrm{ml}$ was transferred into conical flask for rinsing of the vegetables prior to the analysis. $200 \mathrm{ml}$ each of nutrient agar and MacConkey agar were weighed, dissolved in distilled water and sterilized in an autoclave to eliminate any form of contamination prior to the analysis (Cheesbrough, 2005). Subsequently, twenty five grams $(25 \mathrm{~g})$ of each sample was weighed and homogenized with $225 \mathrm{ml}$ sterilized distilled water and serial dilutions were prepared for up to $10^{-3}$ (three dilutions) following the standard methods for plating (Cappucino and Sherman, 1996) by transferring $1 \mathrm{ml}$ from the homogenized samples to the test tubes containing $9 \mathrm{ml}$ of the sterilized distilled water. $1 \mathrm{ml}$ was then taken from the first test tube and transferred into the second test tube after shaking. The same procedure was repeated for the third test tube. After the serial dilution, a volume of $1 \mathrm{ml}$ from each sample suspension was inoculated onto nutrient agar (for total viable count (TVC) enumeration and incubated at $37^{\circ} \mathrm{C}$ for 24 hours and also onto MacConkey agar (for total fecal coliform count enumeration and incubated at an elevated temperature of $45^{\circ} \mathrm{C}$ for 24 hours).

Enumeration of bacteria count was adopted and distinct colonies on surfaces of the culture petri dishes were counted using a colony counter as described by Cheesbrough (2005). The colony counter was switched on and the cultured plate was placed on the surface of the colony counter in an inverted manner showing the colonies clearly for easy counting. A pointer was used to punch on the distinct colonies and the count was displayed on the colony counter. The displayed count was recorded and expressed in colony forming unit per gram (cfu/g) for vegetable samples and colony forming unit per millimeter (cfu/ml) for the water samples.

\section{RESULTS AND DISCUSSION}

Table 1 presents data on total viable count (TVC) of washed and unwashed vegetable water samples compared with WHO recommended standard. Table 1 shows total viable count (TVC (cfu/g), i.e., total number of colonies of unwashed and washed vegetables ranging from $5.4 \times 10^{7}$ to $4.7 \times 10^{4} \mathrm{cfug} / \mathrm{g}$ in carrots, with a reduction of $5.3 \times 10^{7} \mathrm{cfug} / \mathrm{g}$ aftermarket wash; $4.8 \times 10^{3}$ to $1.8 \times 10^{3}$ $\mathrm{cfu} / \mathrm{g}$ in cucumber, with a reduction of $3 \times 10^{3} \mathrm{cfug} / \mathrm{g}$ aftermarket wash; $3.6 \times 10^{6}$ to $2.9 \times 10^{5} \mathrm{cfu} / \mathrm{g}$ in lettuce, with a reduction of $3.31 \times 10^{6} \mathrm{cfu} / \mathrm{g}$ aftermarket wash and $5.6 \times 120^{6}$ to $3.4 \times 10^{4} \mathrm{cfu} / \mathrm{g}$ in tomatoes, with a reduction of $5.26 \times 10^{5}$ to $3.4 \times 10^{4} \mathrm{cfug} / \mathrm{g}$ in tomatoes with a reduction of $5.26 \times 10^{5} \mathrm{cfu} / \mathrm{g}$ aftermarket wash. This reveals that washing of vegetables significantly reduced the total viable count in lettuce and cucumber but very little reduction in carrots and tomatoes; but cannot be compared with the WHO recommended levels of $1 \times 10^{3}$ for unrestricted farm produce as the TVCs highly exceeded the threshold limit.

Table 2 presents data on total fecal coliform counts of vegetable water samples for washed and unwashed vegetables compared with the WHO standard. Table 4.2 shows total fecal coliform count (TFC (cfug/g) for washed and unwashed vegetables ranging between $3.8 \times 10^{5}$ $\mathrm{cfu} / \mathrm{g}$ and $3.4 \times 10^{3} \mathrm{cfu} / \mathrm{g}$ resulting with a decrease of $3.87 \times 10^{5} \mathrm{cfu} / \mathrm{g}$ after washing carrot with distilled water; $2.4 \times 10^{3}$ and $7.6 \times 10^{2} \mathrm{cfu} / \mathrm{g}$; resulting in a decrease of $1.64 \times 10^{3}$ (cfug/ga) in cucumber after wash; $2.4 \times 10^{4}$ and $8.2 \times 10^{3} \mathrm{cfu} / \mathrm{g}$; resulting in a decrease of $1.58 \times 10^{4} \mathrm{cfu} / \mathrm{g}$ in lettuce; $4.7 \times 104$ and $4.4 \times 10^{3} \mathrm{cfu} / \mathrm{g}$; resulting in a decrease of $4.26 \times 10^{4} \mathrm{cfu} / \mathrm{g}$ in tomato, all which exceeded the WHO recommended standard of $1 \times 10^{1}$. Tomatoes 
Table 1. Total Viable Count (TVC) of Vegetable Unwashed and Washed water Compared with WHO Recommended Standard

\begin{tabular}{|c|c|c|c|c|}
\hline $\begin{array}{l}\text { Sample } \\
\text { (vegetables) }\end{array}$ & $\begin{array}{l}\text { TVC } \\
\text { unwashed }\end{array}$ & $\begin{array}{ll}\text { TVC } & \text { (cfug/g) } \\
\text { washed }\end{array}$ & $\begin{array}{ll}\text { TVC } & \text { (cfu/g) } \\
\text { reduction }\end{array}$ & WHO Standard \\
\hline Carrot & $5.4 \times 10^{\prime}$ & $4.7 \times 10^{4}$ & $5.39 \times 10^{\prime}$ & $1 \times 10^{3}$ \\
\hline Cucumber & $4.8 \times 10^{3}$ & $1.8 \times 10^{3}$ & $3 \times 10^{3}$ & $1 \times 10^{3}$ \\
\hline Lettuce & $3.6 \times 10^{6}$ & $2.9 \times 10^{5}$ & $3.31 \times 10^{6}$ & $1 \times 10^{3}$ \\
\hline Tomatoes & $5.6 \times 10^{5}$ & $3.4 \times 10^{4}$ & $5.26 \times 10^{5}$ & $1 \times 10^{3}$ \\
\hline
\end{tabular}

Table .2. Total Fecal Coliform Count (TFC) of Vegetables Sample water Unwashed and Washed Compared with WHO Recommended Standard

\begin{tabular}{|c|c|c|c|c|}
\hline $\begin{array}{l}\begin{array}{l}\text { Sample } \\
\text { (vegetables) }\end{array} \\
\text { (vela }\end{array}$ & $\begin{array}{l}\text { TFC } \\
\text { unwashed }\end{array}$ & $\begin{array}{ll}\begin{array}{l}\text { TFC } \\
\text { washed }\end{array} & \text { (cfug/g) } \\
\end{array}$ & $\begin{array}{l}\text { TFC } \\
\text { reduction }\end{array}$ & WHO Standard \\
\hline Carrot & $3.9 \times 10^{5}$ & $3.4 \times 10^{3}$ & $3.87 \times 10^{5}$ & $1 \times 10^{1}$ \\
\hline Cucumber & $2.4 \times 10^{3}$ & $7.6 \times 10^{2}$ & $1.64 \times 10^{3}$ & $1 \times 10^{1}$ \\
\hline Lettuce & $2.4 \times 10^{4}$ & $8.2 \times 10^{3}$ & $1.58 \times 10^{4}$ & $1 \times 10^{1}$ \\
\hline Tomatoes & $4.7 \times 10^{4}$ & $4.4 \times 10^{3}$ & $4.26 \times 10^{4}$ & $1 \times 10^{1}$ \\
\hline
\end{tabular}

Table 3. Total Viable Count (TVC) of Market Water Samples Used to Wash Vegetables Compared with WHO Standard

\begin{tabular}{|l|l|l|}
\hline Sample & TVC (cfu/ml) & WHO Standard \\
\hline $\begin{array}{l}\text { Water used to wash tomatoes } \\
\begin{array}{l}\text { Water used to wash carrot, } \\
\text { cucumber and lettuce }\end{array}\end{array}$ & $5.3 \times 10^{4}$ & $1 \times 10^{3}$ \\
\hline
\end{tabular}

Table 4. Total Fecal Coliform Count (TFC) of Water Samples used to Wash Vegetables In Compared with WHO Standard

\begin{tabular}{|l|l|l|}
\hline Sample & TFC (cfu/ml) & WHO Standard \\
\hline $\begin{array}{l}\text { Water used to wash tomatoes } \\
\begin{array}{l}\text { Water used to wash carrot, } \\
\text { cucumber and lettuce }\end{array}\end{array}$ & $7.2 \times 10^{3}$ & $1 \times 10^{1}$ \\
\hline
\end{tabular}

contained maximum number of fecal coliform followed by carrots, lettuce and cucumber that had the least number. This shows that fecal counts for carrots and tomatoes had little significance of washed over unwashed, indicating that fecal bacteria still existed in these vegetables.

Table 3 shows total viable count TVC cfu/ml of market water samples used to wash vegetables. Total number of colonies were $5.3 \times 10^{4} \mathrm{cfu} / \mathrm{ml}$ in market water used to wash tomatoes and $4.6 \times 10^{3} \mathrm{cfu} / \mathrm{ml}$ in water used to wash carrots, cucumber and lettuce; resulting in an increase of
$5.2 \times 10^{4}$ and $4.59 \times 10^{5} \mathrm{cfu} / \mathrm{ml}$ over the recommended level of $\mathrm{WHO}$ and $1 \times 10^{3}$. This suggests that prior to use, the market water had become contaminated and may have contributed greatly to the microbial load in vegetables after wash.

Table 4 presents data on identified total fecal coliform count (TFC) of water samples used to wash vegetable. It reveals that water used to wash tomatoes had a total of $7.2 \times 10^{3} \mathrm{cfu} / \mathrm{ml}$, while a total of $3.1 \times 10^{4}$ water used to wash carrot, cucumber and lettuce. When compared with WHO standard, these TFCs were very insignificant with a 
reduction of $7.9 \times 10^{3}$ and $3.099 \times 10^{4} \mathrm{cfu} / \mathrm{ml}$ in both water samples. This could be responsible for the little or no significant reduction in fecal counts on vegetables; especially in carrots and tomatoes, thereby suggesting that available water had become contaminated with fecal contaminants before use.

\section{DISCUSSION}

Results showed that in Samaru Market, sampled vegetables (washed and unwashed) and market water samples presented for analysis were highly contaminated. Carrots had the highest contamination followed by tomatoes, lettuce and the least count was in cucumber. Data and total viable counts shows great differences compared to the World Health Organization (2006) recommended standard for these vegetables. Water samples revealed that water use for washing of tomatoes had maximum counts compared to water use for washing carrot, cucumber and lettuce. Although market wash had a measure of reduction effect on microbial contaminants, it will be suggested that washing fresh produce after purchase is the last opportunity that consumers have to significantly reduce potential microbial load in foods before consumption and it is likely to help reduce food safety risk.

Results for fecal coli form indicated presence of fecal contamination in all samples collected from Samaru market. Tomatoes had maximum level of fecal contaminant prior to wash and after wash, followed by carrots, lettuce and cucumber had the least count. The findings agreed with Arafat and Mohammed (2013) who observed that in twenty-five fresh vegetables found in the market, bacterial coliform and fecal coliform counts were observed from four vegetables namely; tomato, cucumber, green pepper and carrot. This could be attributed to polluted condition of water used for washing of tomatoes which also had maximum fecal counts compared to water used for washing carrots, cucumber and lettuce.

In all samples, several factors may account for high levels of total viable count and total fecal coliform counts on vegetables and water. Among these are the use of polluted irrigation water, sources like feaces and animal waste used as fertilizer, grazing animals, post-harvest care given to vegetables by plunging into close-by rivers where animals not only graze and drink but also excrete in, market related handling; especially where provision for better sanitary standards is lacking (Amoah et al., 2009; Arafat et al. 2013 and Ibrahim and Ojei, 2008).

Despite that there were some level of efficacy of treatments given and improved market levels of microbial counts, none of these could be relied upon since vegetables still had significant measures of microbial load present (Amoah et al., 2009). They therefore recommend that washing vegetables under clean running water could significantly eliminate bacteria load which would help to reduce health risk of food borne infection.

Finally, findings from the study show that total viable counts and total fecal coliform counts is useful in indicating sanitary conditions under which vegetables were produced, processed and marketed in Samaru, Nigeria. This result indicates that the counts obtained from these samples were above permissible standard stipulated by W.H.O for water and vegetables (FAO, 2005).

\section{CONCLUSION}

The analysis was undertaken to determine microbial load on vegetables (carrot, cucumber, tomatoes and lettuce) washed and unwashed and water from these vegetables from Samaru market, Samaru, Zaria. Results reveal that total viable count (TVC) and total fecal coliform count (TFC) were useful in indicating sanitary conditions under which vegetables were produced, processed and marketed in Samaru, Zaria. This was done with a view to understanding the contextual explanation of microbial load on vegetables, sources of microbial contamination and the need for bacteriological water analysis; hence, what precautionary measures to take to ensure safe and wholesome vegetables for human consumption.

It was therefore concluded that Samaru Market sampled vegetables (washed and unwashed) and market water samples were highly contaminated. Carrots had the highest contamination followed by tomatoes, lettuce and the least count was in cucumber. Total viable count significantly differed from the World Health Organization recommended standard for these vegetables. Also, results for fecal coliform showed fecal contamination in all samples collected from Samaru market. Tomatoes had maximum level of fecal contaminant prior to wash and after wash, followed by carrots, lettuce and cucumber that had the least count.

Based on the results, it was concluded that contamination of fresh vegetable produce were attributed to farm practices; which include fecal wastes and undecomposed farmyard manures applied as organic fertilizers/manure, irrigation of farm with polluted water, post-harvest handling, washing and distribution or transportation to the market. Micro-organism could also infest vegetables through damaged surfaces; such as puncture, cuts/splits, bruises that occur during growing, harvesting, transportation and handling. Also, it was inferred that antimicrobial agents used by vegetable sellers; such as detergents and soaps, are not made for consumption, as vegetables could easily absorb these chemicals and experience changes in their taste and flavour (Brandt and Driessen, 2013). Washing vegetables; irrespective of the method used, does not completely eliminate micro-organisms from vegetables. 


\section{RECOMMENDATIONS}

Based on the conclusion drawn, it can be recommended that:

- Consumers should thoroughly wash all fresh produce purchased from the market with running water before consumption in order to reduce health risk.

- The consumers should therefore wash their vegetables thoroughly at home before consumption so as to reduce the spread of food borne illnesses.

- Consumers must avoid cross contamination from food within their homes by food handlers, distributors and field workers by:

i. Purchasing fresh produce wisely, free from bruises, splits, cuts or damage.

- The local government intervenes to protect consumers by ensuring that quality fresh produce is marketed by policy promulgation and implementing strict adherence on how these farm produce are cultivated, harvested and brought to market before it gets to consumers.

- Also governments should educate consumers on the need to properly wash these products before consumption.

\section{REFERENCES}

Amoah P, Pay DR, Abaidoo C, Ernest MA(2009). Improving food hygiene in Africa where vegetables are irrigated with polluted water. West Africa Regional Sanitation and Hygienic Symposium.

Arafat M, Mohammed SON(2013). Microbial quality of some vegetables sold in ED Dwen Town; Sudan. Science alert net (full text/?=ppjbs. 2013. 585.588. .

Asgher AH, Ehbaleh A, Mohemadrza H, Jafar P(2013). Study on the parasitic and microbial contamination of vegetables and the effect of washing procedures in their elimination in Ilam city. Journal of Paramedical Sciences Vol 4 (NO 4). Retrieved on $12^{\text {th }}$ November, 2014.

Beuchat LR, Buck JW, Walcot RR(2003). Recent trends in microbiological safety of fruits and vegetables. Retrieved from online plant Health Progress doi: 10.1094 /PHP-2003-0121-01 rv. Retrieved on $19^{\text {th }}$ August, 2015 .
Brandt K, Driessen S(2013). Handling fresh fruits and vegetable safely. Food safety. University of Minnesota extension. Retrieved from www.extensino.umm.edu/food/foodsafety. Retrieved on 5th August, 2015.

Cheesebrough $\mathrm{M}(2005)$. District laboratory practice in tropical countries. Part 2 second edition. Cambridge University Press. The Edinburgh Building, Cambridge CB2 SRU, unpublished in the United State of America by Cambridge University Press, New York pp. 132-142.

Food and Agricultural Organization, FAO (2005). Manual of Food quality control. 4. Rev. I. microbiological analysis (Andrew w. edit) FAO Food and nutrition paper No. 14/4

Gilman $A F(2002)$. Effect of vegetables types and antimicrobial dippings on survival growth of listeria and E. coli. Int. J. Food Sci and Tech Vol 37 (6), 711-718.

Ibrahim TA, Ojei JB(2008). Microbiological analysis and effect of selected antibacterial agents on microbial lead of vegetables. The Intel J. Microbiol. 2008 (Vol 7(2).

Ihenkuronye $A(2012)$. Saving Nigerians from food poisoning. Punch newspaper. Retrieved from www.punchng.com/editorial/savingNigeriafromfoodpoisoning.

Madigan, Martinko(2006), Retrieved from http://wikipedia atom feed. microorganism, 2015)

Sue R, Demand RD (2015). Six primary nutrients provided by vegetables. Demend Media. RSS Feed. SIGATE. Healthy eating. Retrived from sfgat.com $>$ healthyeating $>$ nutrition $>$ fibre. Retrieved on $13^{\text {th }}$ August, 2015.

Ujah J(2012). Where is Samaru? Loading Map of Samaru and its surrounding. Retrieved from Travelling Luck for Samaru, Nigeria (General). Nigeria. Retrieved on $21^{\text {st }}$ August, 2015.

World Health Organization (WHO) (1995). Food technologies and public health. Geneva. WHO/FNU/95.12. 